\title{
Consumer Motivations for Sharing Luxury Brands
}

\author{
B. Saju
}

Assistant Professor (Sr), VIT Business School, VIT Chennai, India

\section{INTRODUCTION}

Luxury marketers have been watching the rise of sharing startups and the unprecedented consumer acceptance of the same with trepidation. This phenomenon has the potential of scuttling the apple cart of legacy luxury brands and the conventional way of marketing. Thus, the author makes an attempt to dissect the consumer motivations for sharing precious possessions on the one hand and using such services on the other hand. By observing such phenomenon at close quarters using in-depth consumer interviews supplemented by netnographic observation of luxury brand communities, this paper attempts to capture the enablers of a changing consumer psyche in order to chart out strategic implications for brand custodians. In short, this paper examines the following research question a) what are the consumer motivations for sharing as well as using shared luxury brands b) what are the enablers of consumer transition from ownership- centric to experience-centric consumption of luxury.

\section{BACKGROUND}

Luxury, a customary insignia of the amount of wealth one possessed, also delivered a peculiar feel of exclusivity as it enabled elitist symbolism and social class signaling through the cultural capital, aesthetic preferences and refined taste (Bourdieu, 1984; Holt, 1998). Extant research has traditionally considered luxury as superfluous at one end of necessity- excessive continuum (Sekora, 1977; Sombart 1992). 
More recent studies on luxury espouse this perspective as luxury consumption acts as a strong status signal (Saju and Rajan, 2014) and helps novae rich, the new entrants to the upper economic strata, to get visibility and acceptability in the community (Han, Nunes and Dreze, 2010). At the same time, the self-expressive nature of luxury consumption can come handy for consumers to build prestige and self-extension in more subtle ways through precious luxury possessions (Belk, 1988; O’Cass and McEwen, 2004). Though what makes luxury may be debatable one characteristic of it may remain unchanged, luxury is tied to social hierarchy and true luxury will be different from just better premium brands, as Kapferer (2010) puts it "luxury exits because just some people cannot access it”.

According to Belk (2009) sharing is inherent to human behavior, and it helps dissolve possession attachment and expands the extended self. The rise of luxury sharing business models is shape-shiftingg the tradition of ownership and consumption aided and abetted by technological platforms for networking, collaboration and social commerce (Matzler et al, 2015). Luxury sharing models use rental, subscription, rotation or collective ownership of possessions to facilitate access based consumption (Bardhi and Eckhardt, 2012), collaborative consumption, or lateral exchange models (Perren and Kozinets, 2018) wherein an intermediating technology platform brings together seekers and providers and enables economic exchanges. Most of these online rental model makes luxury more accessible thereby democratizing and providing consumers relief from the judgments and personal evaluation related to class categorization that salespeople and other affluenet cosnumers make at retail outlets (Dion and Borazz, 2017). 
These practices also chisel away at the brand immunity benefits enjoyed by some legacy brands (Saju et al., 2017, 2018)

\section{METHODOLOGY}

The author conducted 36 in-depth interviews with luxury consumers (urbane, millennial, uppermiddle, tech- savvy) to get insights into the motivations for luxury sharing. These consumers were identified and approached at luxury brand outlets in three metropolitan cities in India and after obtaining permission, detailed virtual interviews were conducted on a later date using Skype video chat facility. 12 consumers were identified at each location and female consumers outnumbered male counterparts at all locations. The author used phenomenology and an interpretative approach to analyse the outcomes of interviews to bring in specific motivations for sharing as well as using shared luxury products in a culturally immerse context (Thompson: 1989,1997). This was supplemented by a netnography (Kozinets,2002 ) approach to widen the context of luxury sharing to triangulate interview data with posts and engagements about sharing practices by members of two online luxury brand communities.

\section{FINDINGS \& DISCUSSION}

The interpretations of interview data and the triangulation with existing literature and nentographic observations facilitated the emergence of four global themes. The first theme centers around the new-age consumers' (mostly urban elite and millennial) readiness towards buyer-seller role shifts and an unprecedented value maximization orientation even for luxury offerings. This finding contrasts with the traditional view of luxury brands wherein consumers are willing to pay a very high premium to get a feel of exclusivity and to dissuade others to use 
it. The second theme was about consumer affinity for remorseless consumption and variety seeking as provided by sharing platforms which helped them to indulge without moral scruples and also instigated more trials without much resistance. Thus, the first two themes accentuate luxury consumption becoming more fluid and experiential than solid possession of ownership (Bardhi and Eckhardt, 2017), partially assisted by the fact that many brands have been using deliberate inconspicuousness. The third theme was about how luxury sharing platforms enabled consumers to leapfrog in terms of learning the luxury culture, a process which in the past took a considerable amount of time and was only possible through memberships to prestigious reference groups (Dion and Borazz, 2017). This finding is a pointer to the changing dynamics of the social game luxury brands used to facilitate class distinction. Thus, the codes of social games for class distinction and the associated symbols and rituals can be imbibed by novae- rich or even by the aspiring middle class with relative ease as a result of the acculturation provided by platforms (e.g. concierge services). The results of the study set at three different cultural settings (Indian cities are examples of thriving subcultures within a diverse and heterogeneous country) converge to strengthen the underlying similarities in consumption motivations of consumers who actively participate in sharing platforms.

\section{IMPLICATIONS FOR THEORY AND PRACTISE}

This study contributes to luxury branding theory by pointing out the changing motivations of millennial consumers as they are willing to shift to experiential and fluid aspects of possessions more than ownership. Luxury sharing takes shape as a form of ethical and moral consumption as it drives remorseless indulgence and a penchant for variety at the same time making the whole process more democratic. It also helps new seekers of luxury to master the culture codes with ease while chipping away at the exclusivity barrier. Brand custodians should take note of these 
changing aspects of consumption and they need to redesign luxury with a fine emphasis on greater experiential aspects (even for legacy goods) and sharing platform presence to satiate the appetite of growing base of millennial consumers to drive future growth of brands.

\section{REFERENCE}

Bardhi, F., \& Eckhardt, G. M. (2012). Access-based consumption: The case of car sharing. Journal of consumer research, 39(4), 881-898.

Bourdieu, P. (1984). Distinction: a social critique of the judgement of taste. Routledge \& Kegan Paul Ltd originally published in 1979 by Les Editions de Minuit, Paris.

Belk, R. (1988). Possessions and the extended self. Journal of Consumer Research, 15(2), 139168.

Belk, R. (2009). Sharing. Journal of consumer research, 36(5), 715-734.

Dion, D., \& Borraz, S. (2017). Managing status: How luxury brands shape class subjectivities in the service encounter. Journal of Marketing, 81(5), 67-85.

Han, Y. J., Nunes, J. C., \& Drèze, X. (2010). Signaling status with luxury goods: The role of brand prominence. Journal of Marketing, 74(4), 15-30.

Holt, D. B. (1998). Does cultural capital structure American consumption? Journal of Consumer Research, 25(1), 1-25. 
Kapferer, J. N. (2010). Luxury after the crisis: Pro logo or no logo. The European Business Review, (September-October), 42-46.

Kozinets, R. V. (2002). The field behind the screen: Using netnography for marketing research in online communities. Journal of marketing research, 39(1), 61-72.

Matzler, K., Veider, V., \& Kathan, W. (2015). Adapting to the sharing economy. MIT Sloan Management Review, 56(2), 71.O'Cass, A., \& McEwen, H. (2004). Exploring consumer status and conspicuous consumption. Journal of Consumer Behaviour, 4(1), 25-39.

Perren, R., \& Kozinets, R. V. (2018). Lateral Exchange Markets: How Social Platforms Operate in a Networked Economy. Journal of Marketing, 82(1), 20-36.

Saju, B., \& Rajan, K. R. (2014). Impact of corporate social responsibility on customer loyalty and the mediating role of affective identification. Indian Journal of Marketing, 44(9), 7-19.

Saju, B., Harikrishnan, K., \& Anand, S. J. J. (2018). Modeling brand immunity: the moderating role of generational cohort membership. Journal of Brand Management, 25(2), 133-146.

Saju, B., Rangarajan, K., Harikrishnan, K., \& Anand, S. J. J. (2017). New insights on consequences of corporate associations-an investigation of mediators and moderator in Indian context. International Journal of Business Excellence, 12(1), 102-126. 
Sekora, J. (1977). Luxury: The concept in Western thought, Eden to Smollett. Baltimore, London: Johns Hopkins University Press.

Sombart, W. 1992. Leibe, Luxus und Kapitalismus. New edn. Wagenbach.

Thompson CJ, Locander WB, Pollio HR. 1989. Putting consumer experiences back into consumer research: The philosophy and method of existential-phenomenology. Journal of Consumer Research 16(September): 133-146.

Thompson CJ. 1997. Interpreting consumers: a Hermeneutical framework for deriving marketing insights from the texts of consumers' consumption stories. Journal of Marketing Research 34(4): 438-455. 